\title{
PENGUJIAN KETETAPAN MAJELIS PERMUSYAWARATAN RAKYAT TERHADAP UNDANG-UNDANG DASAR 1945
}

\author{
Demas Brian Wicaksono \\ Fakultas Hukum Universitas 17 Agustus 1945 Banyuwangi \\ J1. Laksda Adi Sucipto, Taman Baru, Kec. Banyuwangi, Kabupaten Banyuwangi, Jawa Timur \\ Email: bimapunkrock@yahoo.co.id
}

\begin{abstract}
Indonesia is a State of Law upholding the supremacy of law by adjusting legal norms in the hierarchical level, shown by the written regulation in Article 7 Law No.12 Year 2011 on the Formulation of Legislation, which makes legal hierarchy become an important principle in legislation system. In the legislation process, regulations seem to be changeable, as it can be seen from the provision of People's Consultative Assembly (TAP MPR) No.XX/MPRS/1996 as well as the current Laws. Having said that, the hierarchical position of TAP MPR appears to have no legal provisions and there is legal vacuum in the examination towards higher legal level such as 1945 Constitution. Therefore, reformulation of TAP MPR hierarchical status in Law No.12 Year 2011 on the Formulation of Legislation is needed, and evaluation of institution that can examine TAP MPR is indeed crucial
\end{abstract}

Keyword: Formulation, Hirarchy, TAP MPR

\begin{abstract}
ABSTRAK
Indonesia sebagai Negara hukum yang menjunjung tinggi supremasi hukum dengan mengatur norma hukum dalam tataran hierarki, tertulis juga dalam Pasal 7 Undang-undang Nomor 12 Tahun 2011 tentang Pembetukan Peraturan Perundang-undangan, maka hierarki menjadi asas penting dalam sistem peraturan perundang-undangan. Dalam proses pembentukan perundangundangan peraturan yang mengaturpun juga berubah ubah, mulai dari Tap MPR Nomor XX/MPRS /1966 hingga undang-undang saat ini. Tetapi dalam kedudukan Ketetapan MPR (TAP MPR) mengalami ketidak pastian hukum dalam hierarki dan kekosongan hukum dalam pengujiannya terhadap peraturan di atasnya yaitu Undang-Undang Dasar 1945. Maka perlu adanya formulasi kedudukan TAP MPR dalam hierarki dalam Undang-Undang Nomor 12 Tahun 2011 tentang Pembentukan Peraturan Perundang-Undangan dan Lembaga apa yang dapat Menguji TAP MPR.
\end{abstract}

Kata Kunci: Formulasi, Hierarki, TAP MPR, Uji Materiil

\section{PENDAHULUAN}

Pancasila sebagai dasar Negara Indonesia yang digunakan sebagai pedoman dalam kehidupan berbangsa dan bernegara. Dengan kata lain bahwasanya segala bentuk kebijakan dan kegiatan masyarakat Indonesia berlandaskan pada nilai-nilai pancasila. Termasuk dalam pembentukan peraturan hukum, yang dimana kebijakan hukum adalah sebuah kebijakan yang mengikat untuk mengatur masyarakat Indonesia untuk lebih baik.

Dengan berlandaskan pada Pasal 1 Ayat 3 Undang-undang Dasar 1945 yang isinya 
"Negara Indonesia adalah Negara hukum"1. Maka Indonesia dalam segala aspek kehidupan dan dalam hal apapun haruslah berlandaskan peraturan hukum. Dan sebagai negara yang mendaulatkan diri sebagai negara hukum, salah satu upaya untuk menjaga kedudukan konstitusi yang bahwasanya adalah perwujudan dari pancasila dalam norma hukum, maka tatanan norma hukum harus menjadi sebuah perlindungan hukum, sehingga dalam segala aspek ketatanegaraan, kehidupan bermasyarakat, dan pembuatan peraturan perundang-undangan haruslah berlandaskan hukum, yaitu dengan berlandaskan amanat konstitusi .

Dan ketika disandingkan dengan prinsip Negara hukum yang meletakkan landasan bahwa setiap tindak hokum (rechtshandelingen) lembaga atau pejabat Negara/pemerintah di lapangan hokum ketanegaraan atau pemerintahan harus dilakukan menurut hukum, baik hukum yang tertulis (geschrevenrecht) maupun yang tidak tertulis (ongeschrevenrecht). Dengan demikian, setiap tindakan pembentukan peraturan perudang-undangan harus pula dilakukan berdasarkan hukum. Pembentukan peraturan perundang-undangan tanpa alas hukum (landasanyuridis) pada dasarnya merupakan tindakan melanggar hokum (onrechmatig). Oleh sebab itu suatu peraturan perundang-undangan yang lahir dari tindakan pembentukan peraturan perundang-undangan yang onrechtmatig harus dinyatakan tidak sah atau bertentangan dengan hukum. ${ }^{2}$

Dalam hal membentuk peraturan perundang-undangan di Indonesia, ada beberapa tahapan dan ketentuan supaya peraturan pembentukan peraturan perundang-undangan sesuai dengan kondisi dan pola kebutuhan masyarakat Indonesia. Yaitu tertuang dalam Pasal 5 dan Pasal 5 Undang-UndangNomor 12 Tahun 2011 tentang Pembentukan peraturan perundang-undangan yang isinya $:^{3}$

Dalam membentuk Peraturan Perundang-undangan harus dilakukan berdasarkan pada asas Pembentukan Peraturan Perundang-Undangan yang baik, yang meliputi:

a. Kejelasan tujuan,

b. Kelembagaan atau pejabat pembentuk yang tepat,

c. Kesesuaian antara jenis, hierarki dan materi muatan,

d. Dapat dilaksanakan,

e. Kedayagunaan dan kehasilgunaan,

f. Kejelasan rumusan, dan

g. Keterbukaan"

dan Pasal 6 menjelaskan Materi muatan Peraturan Perundang-undangan harus mencerminkan asas: ${ }^{4}$
a. pengayoman
b. kemanusiaan
c. kebangsaan
d. kekeluargaan,
e. kenusantaraan
f. bhinneka tunggal ika

\footnotetext{
${ }^{1}$ Pasal 1 ayat 3 Undang-Undang Dasar Republik Indonesia 1945

${ }^{2}$ Widodo Ekatjahjana, Pembentukan Peraturan Perundang-Undangan Dasar-Dasar dan Teknik Penyusunannya.PT. CITRA ADITYA BAKTI, Bandung, 2008. Hlm.21

${ }^{3}$ Pasal 5 Undang-UndangNomor 12 Tahun 2011 tentangPembentukanPeraturanPerundang-Undangan

${ }^{4}$ Pasal 6 Udang-UndangNomor 12 Tahun 2011tentangPembentukanPeraturanPerundang-Undangan
} 
g. keadilan

h. kesamaan kedudukan dalam hukum dan pemerintahan

i. ketertiban dan kepastian hukum dan/atau

j. keseimbangan, keserasian, dan keselarasan".

Sehingga segala bentuk materi muatan peraturan perundang-undangan wajib berpedoman pada asas peraturan dasar atau disebut Asas-Asas Umum Pemerintahan yang Baik (AAUPB) dalam pembentukan peraturan perundang undangan yaitu tercantum dalam Pasal 5 dan Pasal 6 Undang-Undang Nomor 12 tahun 2011 tentang pembentukan peraturan perundang-undangan. Salah satu asas yang terpenting dalam pembentukan peraturan perundang-undangan adalah asas hierarki.

Asas hierarki perundang-undangan yang tertuang pada Pasal 7 ayat 1 Undang-Undang Nomor 12 tahun 2011 tentangPembentukan Peraturan Perundang-Undangan yang isinya "jenis peraturan Perturan-Undangan terdiri atas:

a. Undang-Undang Dasar Republik Indonesia tahun 1945 ,

b. Ketetapan majelis permusyawaratan rakyat,

c. Undang-Undang/Peraturan Pemerintah Pengganti Undang-Undang,

d. Peraturan Pemerintah,

e. Peraturan Presiden,

f. Peraturan Daerah Provinsi,

g. Peraturan Daerah kabupaten/ kota". 5
Sehingga sudah jelas bahwa hierarki dalam peraturan perundang-undangan sangatlah menjadi hal yang penting dalam menjaga system ketatanegaraan Indonesia, yang dalam hal ini adalah peraturan perundang-undangan.

Tetapi ada muatan materi perundang-undang yang sifatnya tidak sesuai yaitu pada hierarki perundang-undang pada pasal 7 Undang-Undnang Nomor 12 tahun 2011 tentang Pembentukan Peraturan PerundangUndangan, yang dimana dalam isinya memasukkan kembali TAP MPR dalam hierarki perundang-undangan. Menurut penulis ada dua hal yang tidak lazim dalam pembangunan tata negara di Indonesia yaitu TAP MPR diposisikan diatas undang-undang yang sudah barang tentu merupakan posisi dilematis dan tidak ada pengaturan terkait lembaga yang dapat menguji Ketetapan Majelis Permusyawaratan Rakyat (MPR RI) apabila bertentangan dengan Undang-Undang Dasar dan Pancasila.

Dan pada prinsip Negara hokum juga mengisyaratkan bahwa setiap pembentukan peraturan perundang-undangan harus dapat diuji keabsahan hukumnya (legal validity) melalui lembaga pengujian peraturan perundang-undangan. Lembaga pengujian ini dapat berupa lembaga yudisial, lembaga non-yudisial ataupun campuran, yaitu lembaga yudisial dan lembaga non-yudisial. Dalam system pen-

\footnotetext{
${ }^{5}$ Pasal 7 Ayat 1 Undang-UndangNomor 12 Tahun 2011 tentang Pembentukan PeraturanPerundang-Undangan.
} 
gujian peraturan perundang-undangan di Indonesia, seharusnya dikembangkan adalah jenis pengujian

Agar untuk menjaga semangat pembangunan hukum tata negara di Indonesia, dan menjaga kepastian hukum hingga menghindari kekosongan hukum dalam kedudukan dan pengujian TAP MPR, perlu adanya rumusan yang bisa melaksanakan pengujian TAP MPR apabila tidak sesuai dengan Konstitusi dan Pancasila. Yaitu dengan cara memasukkan peraturan Lembaga yang dapat menguji dan memasukkan materi muatan pengujian TAP MPR dalam Undang-Undang Nomor 12 Tahun 2012 tentang Pembentukan Peraturan Perundang-Undangan.

Dari latar belakang adanya kekosongan hukum dalam kedudukan dan pengujian Ketetapan Majelis Permusyawaratan Rakyat (TAP MPR), Penulis Mengambil Judul dalam karya tulis ilmiah ini adalah "PENGUJIAN $\begin{array}{llr}\text { KETETAPAN } & \text { MAJELIS } & \text { PER- } \\ \text { MUSYAWARATAN } & \text { RAKYAT } & \text { TERHADAP } \\ \text { UNDANG-UNDANG DASAR } & \text { 1945”, dengan }\end{array}$ rumusan masalah bagaimana seharusnya pengaturan kedudukan Ketetapan Majelis Permusyawaratan Rakyat dalam hierarki perundang-undangan?; Bagaimana seharusnya pengaturan pengujian Ketetapan Majelis
Permusyawaratan Rakyat terhadap UndangUndang Dasar 1945?

\section{PEMBAHASAN}

\section{Pengaturan Kedudukan Ketetapan Majelis} Permusyawaratan Rakyat dalam Hierarki

\section{Perundang-Undangan}

Indonesia sebagai negara yang menjunjung supremasi hukum dalam pelaksanaan kehidupan bernegara, mengimplementasikan negara hukum salah satunya dengan mengatur hierarki norma hukum, sebagai bentuk dari pada menjaga norma hukum. Perlu adanya pengaturan hierarki norma hukum yang berlaku, yang dimana dalam hierarki tersebut merupakan pelaksanaan nilai dasar perundang-undangan yaitu pada asas hierarki.

Keberadaan hierarki peraturan perundangundangan dalam kehidupan ketatanegaraan Indonesia merupakan sebuah sistem untuk menjaga adanya konsistensi dan ketaatasasan dalam hukum positif di Indonesia. Bahwa dilarang terdapat pertentangan antara suatu norma dengan norma yang lain, semata demi memberi jaminan kepastian hukum kepada masyarakat. Makna tata urutan atau hierarki atau tingkatan dalam tata hukum/peraturan perundang-undangan adalah: ${ }^{6}$

a. Peraturan hukum atasan merupakan dasar hukum pembentukan peraturan hukum bawahan.

\footnotetext{
${ }^{6}$ Retno Anis sebagaimana dikutip oleh Dian Agug Wicaksono, Jurnal Konstitusi, Volume 10, Nomor 1, Maret 2013. Hlm. 152.
} 
b. Peraturan hukum bawahan merupakan pelaksanaan peraturan hukum atasan, oleh karena itu kedudukannya lebih rendah dan materi muatannya tidak boleh bertentangan.

c. Manakala terdapat dua peraturan perundang-undangan dengan materi muatan mengatur materi sama dan dengan kedudukan sama maka berlaku peraturan perundang-undangan baru.

Menjadi jelas kemudian bahwa keberadaan hierarki peraturan perundang-undangan adalah semata untuk menjaga konsistensi antara satu norma dengan norma yang lain. Secara sepintas sebenarnya penjabaran penjabaran di atas adalah berangkat dari asas hukum lex superiori derogat legi inferiori, lex specialis derogat legi generalis, dan lex posteriori derogat legi priori. Menjadi terang bahwa keberadaan hierarki mempunyai tujuan tertentu dalam pembangunan hukum Indonesia. $^{7}$

Dari perspektif historis teoritis, pemikiran strukturalisme produk hukum dikenalkan oleh Hans Kelsen yang menyebut bahwa setiap norma selalu memiliki norma dasar (grundnorm) yang mendasari lahirnya berikutnya (norm), yang kemudian dikembangkan lebih lanjut oleh muridnya Hans Nawiasky yang mendetailkan pemikiran Kelsen terkait stufenbau der rechsordnung, ${ }^{8}$ secara singkat sebagai berikut:

A norm is valid because and in so far as it was created in a certain way, that is, in a way dtermined by another norm; and this latter norm, then, represents the basis of the validity of the farmer norm. The relation between the norm determining the creation of another norm, and the norm created in accordance with this dtermination, can be visualized by picturing a higher and lowerlevel ordering of norm. The norm determining the creation is the higher-level norm, the norm created in accordance with this determination is the lower level norm. ${ }^{9}$

Hierarki dalam sistem ketatanegaraan Indonesia diartikan sebagai berikut “penjenjangan setiap jenis peraturan perundang-undangan yang didasarkan pada asas bahwa peraturan perundang-undangan yang lebih rendah tidak boleh bertentangan dengan peraturan perundang-undangan yang lebih tinggi". ${ }^{10}$

Undang-Undang Dasar 1945 sebelum amandemen, tidak menetapkan dalam pasalpasalnya tentang kedudukan atau hierarki peraturan perundang-undangan di Indonesia, selain itu undang-undang dasar 1945 hanya menyatakan secara tegas beberapa jenis peraturan perundang-undangan, yaitu undang-undang, peraturan pemerintah

\footnotetext{
${ }^{7}$ Ibid.

${ }^{8}$ Hanno Kaiser, "Notes on Hans Kelsen's Pure Theory of Law (1st Ed.)", http://www.nigerianlawguru.com/articles/jurisprudence/KELSEN-PURETHEORY.pdf(diakses pada 20 Februari 2018 jam 22.00 WIB

${ }^{9}$ Hans Kelsen (Translate by Max Knight), Pure Theory of Law (Berkley: Berkley University Press, 1967), Hlm. 221.

${ }^{10}$ Rimdan, Kekuasaan Kehakiman Pasca-Amandemen Konstitusi, Kencana, 2012. Hlm 34-35.
} 
pemerintah pengganti undang-undang, dan peraturan pemerintah. Kedudukan atau hierarki serta jenis peraturan perundangundangan tersebut kemudian secara tegas ditetapkan dalam ketetapan Majelis Permusyawaratan Rakyat sementara Nomor XX/ MPRS 1966 tentang memorandum DPRGR mengenai Sumber Tertib Hukum Dan Tata Urutan Peraturan PerundangUndangan Republik Indonesia. ${ }^{11}$

Dalam perkembangannya hierarki peraturan perundang-undangan dalam peraturannya mengalami beberapa perubahan mulai dari

1. Tap MPR Nomor XX/ MPRS /1966

2. Tap MPR Nomor III/ MPR / 2000

3. Undang-Undang Nomor 10 Tahun 2004 tentang Pembentukan Peraturan Perundang-Undangan

4. Undang-Undang Nomor 12 Tahun 2011 tentang Pembentukan Peraturan Perundang-Undangan

Dalam perubahan keempat pada pengaturan pembentukan peraturan perundang-undangan yaitu Undang-Undang Nomor 12 tahun 2011 tentang Pembentukan Peraturan Perundang-Undang. Pada pasal 7 undang-undang ini dimasukkannya kembali Ketetapan MPR (Tap MPR).
Pada perkembangan Ketetapan MPR (TAP MPR) salah satunya menjelaskan pengertian Ketetapan MPR yang ada pada Ketetapan MPR Nomor II/MPR/2000 menjelaskan "Ketetapan (TAP) MPR" diformulasikan sebagai :

a. Berisi arah kebijakan penyelenggaraan negara

b. Berisi rekomendasi majelis kepada Presiden dan Lembaga tinggi negara tertentu lainnya mengenai pelaksanaan putusan majelis yang harus dilaporkan pelaksanaannya dalam sidang tahunan berikutnya;

c. Mempunyai kekuatan hukum mengikat ke luar dan ke dalam majelis

d. Menggunakan nomor putusan majelis. ${ }^{12}$ Sedangkan pada pasal 3 ayat 2 Ketetapan MPR Nomor III/MPR/2000 tentang Sumber Hukum dan Tata Urutan PerundangUndangan menjelaskan pasal ini bahwasanya pengertian Ketetapan MPR ialah "Ketetapan Majelis Permusyawaratan Rakyat Republik Indonesia merupakan putusan Majelis Permusyawaratan Rakyat sebagai pengemban kedaulatan rakyat yang ditetapkan dalam sidang Majelis Permusyawaratan Rakyat" ${ }^{13}$

Menurut Widodo Ekatjahjana untuk memilih ketentuan mana yang akan diikuti, terlebih dahulu seyogianya diperiksa apakah

\footnotetext{
${ }^{11}$ Maria Farida sebagaimana dikutip oleh Rimdan. Ibid.

${ }^{12}$ Ketetapan Majelis Permusyawaratan Rakyat Nomor II/MPR/2000

${ }^{13}$ Pasal 3 ayat 2 Ketetapan Majelis Permusyawaratan Rakyat Nomor III/MPR/200 tentang Sumber Hukum dan Tata Urutan Perundang-Undangan.
} 
ada atau tidak ketentuan tentang bagaimana langkah yang harus ditempuh oleh MPR ketika berhadapan dengan pengertian hukum Ketetapan MPR yang dibius itu. ${ }^{14}$

Selanjutnya penulusuran terhadap produkproduk hukum MPR memperlihatkan, bahwa MPR sesungguhnya memiliki kewenangan untuk menginterpretasikan putusan-putusannya. Pasal 4 Ketetapan MPR Nomor II/MPR/1999 sebagaimana telah diubah oleh ketetapan MPR Nomor II/MPR/2000 yang mengatur, bahwasanya majelis mempunyai wewenang: ${ }^{15}$

a. Membuat putusan-putusan yang tidak dapat dibatalkan oleh Lembaga Negara yang lain, termasuk penetapan GarisGaris Besar Haluan Negara;

b. Memberikan Penjelasan yang bersifat penafsiran terhadap putusan-putusan Majelis;

c. Menyeleseikan pemilihan dan selanjutnya mengangkat Presiden dan Wakil Presiden;

d. Meminta pertanggung jawaban dari presiden mengenai pelaksanaan GarisGaris Besar Haluan Negara dan menilai pertanggungjawaban tersebut;

e. Mencabut kekuasaan dan memberhentikan Presiden dalam masa jabatannya apabila Presiden sungguh-sungguh melanggar
Garis-Garis Besar Haluan Negara dan/atau Undang-Undang Dasar.

f. Mengubah Undang-Undang Dasar

g. Menetapkan Peraturan Tata Tertib Majelis;

h. Menetapkan pimpinan majelis yang dipilih dari dan oleh anggota

i. Mengambil dan/atau memberi keputusan terhadap anggota yang melanngar sumpah /janji anggota.

Berdasarkan ketentuan Pasal 4 (huruf b) Ketetapan MPR Nomor II/MPR/2000 ini, maka jelaslah, bahwa MPR memiliki wewenang untuk memberikan penjelasan yang bersifat penafsir terhadap putusanputusan majelis. Jadi, dalam hal ternyata terdapat pengertian yuridis tentang Ketetapan MPR yang dubuis itu, MPR dapat memberikan penjelasan yang bersifat penafsiran mengenai soal pengertian mana yang harus diikuti. ${ }^{16}$

Melihat perkembangan Ketetapan MPR yang kewenangannya mengatur masyarakat hal ini tentunya menimbulkan kekosongan hukum dalam pengujian dan posisi TAP MPR di dalam hierarki Peraturan PerundangUndangan pada Undang-Undang Nomor 12 tahun 2011 tentang Pembentukan Peraturan Perundang-Undangan.

\footnotetext{
${ }^{14}$ Widodo Ekatjahjana dan Totok Sudaryanto, Sumber Hukum Tata Negara Formal di Indonesia, PT.Citra Aditya Bakti, Bandung, 2001. Hlm.45

${ }^{15}$ Pasal 4 Ketetapan MPR Nomor II/MPR/1999 sebagaimana telah diubah oleh ketetapan MPR Nomor II/MPR/2000

${ }^{16}$ Widodo Ekatjahjana dan Totok Sudaryanto, Sumber Hukum Tata Negara Formal di Indonesia.Op.Cit. Hlm. 46
} 
Dan apabila di korelasikan Pancasila, Undang-Undang Dasar 1945, dan Keteapan MPR dilihat dari sistem norma hukum Negara Republik Indonesia, maka Staatfundamentalnorm Pancasila, Verfassungnorm UUD 1945, Grundgesetznorm Ketetapan MPR, dan Gesetznorm Undang-Undang merupakan suatu bagian dari sistem norma hukum Negara Republik Indonesia. Staatfundamendalnorm Pancasila yang merupakan pokok-pokok pikiran yang terkandung dalam pembukaan UUD 1945 adalah sumber dan dasar bagi pembentukan pasal-pasal dalam verfasungnorm UUD 1945, sedangkan aturan yang ada dalam verfassungnorm UUD 1945 merupakan sumber dan dasar bagi pembentukan aturanaturan dalam Grundgesetznorm Ketetapan MPR dan juga sekaligus merupakan sumber dan dasar bagi pembentukan Gesetznorm Undang-Undang. Oleh karena itu, Grundgesetnorm Ketetapan MPR itu juga merupakan aturan dasar negara/ aturan pokok negara diatas Gesetznorm Undang-Undang, maka Grundgesetznorm Ketetapan MPR ini juga merupakan sumber bagi pembentukan norma-norma hukum dalam Gesetznorm Undang-Undang yang merupakan peratura perundang-undangan yang tertinggi di Negara Republik Indonesia. ${ }^{17}$

Dan hingga sampai pada pembentukan Undang-Undang Nomor 12 Tahun 2011 tentang Pembentukan Peraturan Perundang-
Undangan Ketetapan MPR masih tersisa 6 ketetapan, diantaranya :

a. Tap MPR Nomor XXV/MPRS/1966 tentang pembubaran partai komunis Indonesia, Pernyataan sebagai organisasi terarang di seluruh wilayah Negara Republik Indonesia bagi Partai Komunis Indonesia dan Larangan setiap kegiatan untuk menyebarkan atau mengembangkan Faham atau ajaran Komunis/Marxise-Leninisme.

b. Tap MPR Nomor XVI/MPR/1998 tentang Politik Ekonomi dalam Rangka Demokrasi Ekonomi.

c. Tap MPR Nomor XI/MPR/1998 tentang Penyelenggara Negara yang bersih dan Bebas Korupsi, Kolusi, dan Nepotisme.

d. Tap MPR Nomor VI/MPR/2001 tentangEtika Kehidupan Berbangsa

e. Tap MPR Nomor VII/MPR/2001 tentang Visi Indonesia masa depan

f. Tap MPR Nomor IX/MPR2001 tentang Pembaruan Agraria dan Pengelolaan Sumber Daya Alam.

Dengan Tap MPR yang hanya berjumlah 6 ketetapan tersebut menjadi pertanyaan kemudian mengapa Tap MPR dimasukkan kembali dalam hierarki peraturan perundangundangan. Tentu jika argumentasi yang diajukan hanya semata untuk melakukan

\footnotetext{
${ }^{17}$ Maria Farida Indrati S, Ilmu Perundang-Undangan 1,PT. Kanisisu, Jogjakarta, 2007. Hlm. 65-66
} 
preverse and strengthen terhadap keberadaan Tap MPR, ${ }^{18}$ menjadi tidak relevan jika dibandingkan dengan implikasi yang ditimbulkan oleh re-eksistensi Tap MPR dalam hierarki peraturan perundangundangan. Tidak masuknya Tap MPR dalam hierarki peraturan tentu tidak dapat dimaknai sempit bahwa Tap MPR menjadi tidak berlaku dan membuat kewibawaan kelembagaan MPR sirna. Bahwa masuk tidaknya Tap MPR dalam hierarki perundang-undangan adalah pilihan kebijakan (Legal Policy) pembentukan Undang-Undang, tetapi tentu harus tetap mempertahankan implikasi yang ditimbulkan dari pilihan kebijakan tersebut. ${ }^{19}$

Sehingga tetap menjadi pertanyaan lembaga apa yang bisa menguji Ketetapan MPR dan Sudah sesuaikan Kedudukan MPR dalam Hierarki Perundang-Undangan yang menempatkan Ketetapan MPR berada pada di bawah Undang-Undang Dasar dan di atas undang-undang.

Maka dari itu dalam dalam tata urutan hierarki perundang-undangan Ketetapan MPR adalah produk daripada legislatif maka tidak seharusnya ketetapan MPR berada pada urutan di bawah Undang-Undang Dasar 1945 dan di atas Undang-undang. Sehingga Pemerintah bersama DPR perlu segera merevisi pasal 7 ayat 1 Undang-Undang
Nomor 12 Tahun 2011 tentang Pembentukan Peraturan Perundang-Undangan. Dengan menempatkan posisi Ketetapan MPR berada sejajar dengan Undang-Undang. Karena MPR adalah bagian daripada legislatif.

\section{Pengaturan Pengujian Ketetapan Majelis} Permusyawaratan Rakyat terhadap Undang-Undang Dasar 1945

Sebagaimana diuraikan di pembahasan sebelumnya bahwa hierarki peraturan perundang-undangan adalah murni bentuk pilihan kebijakan pembentuk UndangUndang. Namun, yang dipermasalahkan selain penempatan Tap MPR dalam hierarki Peraturan Perundang-Undangan, namun lebih mempemasalahkan implikasi yang ditimbulkan dari pilihan kebijakan tersebut. Salah satu implikasi yang membuat penempatan Tap MPR dalam hierarki menjadi dilematis adalah potensi pertentangan Tap MPR dengan konstitusi. Beberapa indikasi munculnya pertentangan Tap MPR dengan Konstitusi dapat dilihat dari uruaian berikut ini :

Pertama, merujuk pada Pasal 22 A UndangUndang Dasar 1945, mengamanatkan untuk membentuk undang-undang tentang tata cara pembentukan undang-undang, yang kemudian diwujukan dengan Undang-Undang Nomor 10 tahun $2004,{ }^{20}$ atau yang terbaru dengan

\footnotetext{
${ }^{18}$ Risalah Rapat Panitia Khsusus Rancangan Undang-Undang tentang Pemebentukan peraturan perundangundangan, tertanggal 2 Maret 2011

${ }^{19}$ Dian Agug wicaksono, Jurnal Konstitusi. Op.Cit. Hlm. 169.

${ }^{20}$ Pasal 8 Undang-Undang Nomor 10 tahun 2004 tentang Pembetukan Peraturan Perundang-Undangan
} 
Undang-Undang Nomor 12 Tahun 2011 tentang Pembentukan Peraturan PerundangUndangan, ${ }^{21}$ yang mengatur hal yang sama bahwa materi muatan undang-undang merupakan pengaturan lebih lanjut mengenai ketentuan Undang-Undang Dasar 1945. Dengan pendekatan norma tersebut maka mutatis mutandis kedudukan Tap MPR di bawah Undang-Undang Dasar 1945 terderogasi dengan norma organik sebagaimana diamanatkan konstitusi, karena yang dapat menjabarkan norma konstitusi lebih lanjut hanya UndangUndang. ${ }^{22}$

Kedua, walaupun secara tegas Tap MPR tidak menjabarkan lebih lanjut ketentuan konstitusi sebagaimana dibahas di atas, tetapi sebagai konsekuensi keberadaan hierarkis Tap MPR membuat materi muatan Tap MPR dimungkinkan untuk dijabarkan lebih lanjut oleh jenis peraturan perundang-undangan dibawahnya. Bahwa sebagaimana telah dijelaskan sebelumnya, konsekuensi hierarkisitas norma adalah tidak menghendaki adanya pertentangan dan mengarah pada koherensi norma, untuk itu keberadaan Tap MPR di bawah Undang-Undang Dasar 1945 dan di bawah perundang-undangan yang membawa konsekuensi materi muatan Tap MPR akan dijabarkan lebih lanjut oleh peraturan perundang-undangan di bawahnya.
Menjadi problematika jika secara materi muatan saja Tap MPR ada potensi bertentangan dengan UUD tetapi dimungkinkan untuk dijabarkan lebih lanjut oleh peraturan perundang-undangan di bawahnya. ${ }^{23}$

Ketiga, merujuk pada Pasal 28J ayat 2 Undang-Undang Dasar 1945, disebutkan dengan jelas bahwa yang dapat melakukan pembatasan terhadap hak asasi manusia hanya dengan Undang-Undang, dan bukan dengan produk hukum yang lain. Tetapi, jika menelaah salah satu diantara Tap MPR yang masih berlaku yaitu Tap MPRS Nomor XXV/MPRS/1966 tentang pembubaran Partai Komunis Indonesia, pernyataan sebagai Organisasi terlarang di Seluruh Wilayah Negara Republik Indonesia bagi Partai Komunis Indonesia dan larangan setiap kegiatan untuk menyebarkan atau mengembangkan faham atau ajaran Komunis/MarxismeLeninisme, disana terllihat jelas sarat dengan nuansa pembatasan hak-hak asasi manusi. ${ }^{24}$

Keempat, sebagai tindak lanjut dari adanya potensi pertentangan dengan konstitusi dan indikasi pembatasan hak konstitusional warga negara, maka perlu dipikirkan ke mana upaya hukum yang dapat ditempuh apabila indikasi dan potensi secara nyata terjadi. Sejauh penelusuran secara yuridis formal tidak diketemukan upaya hukum jika indikasi dan

\footnotetext{
${ }^{21}$ Pasal 10 Undang-Undang Nomor 12 Tahun 2012 tentang Pembentukan Peraturan Perundang-Undangan

${ }^{22}$ Dian Agug wicaksono, Jurnal Konstitusi. Op.Cit. Hlm. 170.

${ }^{23} \mathrm{Ibid}$.

${ }^{24}$ Ibid.
} 
potensi tersebut benar-benar terjadi. Tentu hal ini menjadi sebuah ketimpangan bagi negara yang telah berdaulat diri sebagai negara hukum. Dalam konteks negara hukum tentu tidak ada norma yang lepas dari mekanisme pengawasan. Mekanisme pengujian peraturan perundang-undangan adalah salah satu sentral untuk mengawasi materi muatan agar senantiasa koheren dan melindungi hak-hak warga negara. Namun dalam konteks keberadaan Tap MPR di dalam hierarki peraturan perundang-undangan tidak ditemukan satu pun pengujian Tap MPR. Hal inilah yang jamak disebut sebagai terra incognita ${ }^{25}$ yaitu menjadi wilayah tak tertuan karena tidak ada lembaga yang mempunyai kewenangan untuk melakukan pengujian terhadap Tap MPR. Terhadap kondisi kekosongan hukum ini muncul pandangan penulis untuk menyeleseikan permasalahan pengujian.

Memposisikan Tap MPR sejajar dengan Undang-Undang dari segi penilaian unsur materiil jika tap MPR tersebut mengatur hal yang sama, maka dapat dilakukan judical review Tap MPR terhadap Undang-Undang Dasar. Dengan cara merevisi ketentuan hierarki pada pasal 7 Undang-Undang Nomor 12 Tahun 2011 tentang Pembentukan Peraturan Perundang-Undangan yang posisinya diatas daripada Undang-Undang. Dan pandangan ini reaaltif dapat diikhtiarkan dalam konteks negara hukum Indonesia, mengingat adanya preseden putusan Mahkamah Konstistusi yang menyatakan Niet Onvankelijkverklaard (NO) dalam perkara permohonan pengujian perpu terhadap UUD.

Dengan pemikiran diatas, diharapkan implikasi terra inconita sebagai implikasi keberadaan Tap MPR di dalam hierarki peraturan perundang-undangan dapat dipecahkan. Tentu dalam konteks negara hukum jaminan atas kepastian hukum adalah sesuatu yang mutlak dijamin.

\section{KESIMPULAN}

Maka dari itu dalam dalam tata urutan hierarki perundang-undangan Ketetapan MPR (TAP MPR) Secara materil adalah produk daripada legislatif dan tidak seharusnya ketetapan MPR berada pada urutan di bawah Undang-Undang Dasar 1945 dan di atas Undang-Undang. Dan TAP MPR mempunyai 2 sifat yaitu mengatur keluar (Recheling) dan kedalam (Bechikking) Sehingga perlu adanya revisi yang harus dilakukan oleh Pemerintah bersama DPR merevisi pasal 7 ayat 1 UndangUndang Nomor 12 Tahun 2011 tentang Pembentukan Peraturan Perundang-Undangan. Yaitu dengan menempatkan posisi Ketetapan MPR(TAP MPR) berada dibawah UndangUndang. Dan tidak boleh diatas dari UndangUndang karena TAP MPR adalah lembaga bagian daripada legislatif.

\footnotetext{
${ }^{25}$ Michael Kirby sebagimana dikutip oleh Dian Agung Wicaksono, Ibid.
} 
Memosisikan TAP MPR di bawah Undang-Undang adalah solusi, karena TAP MPR mempunyai dua sifat pengaturannya yaitu kedalam (Bechiking) dan keluar (recheling). Maka TAP MPR yang mengatur ke luar (Recheling) dapat diujikan terhadap Undang-Undang Dasar dapat dilaksankan. Mengingat secara materil isi dari pada pengaturan TAP MPR sama dengan UndangUndang. Maka dengan cara merevisi ketentuan hierarki pada pasal 7 UndangUndang Nomor 12 Tahun 2011 tentang Pembentukan Peraturan PerundangUndangan yang memosisikan TAP MPR dibawah Undang-Undang supaya dapat diujikan terhadap Undang-Undang Dasar sebagaimana perpu yang dapat di ujikan terhadap Undang-Undang Dasar 1945.

\section{SARAN}

1. Untuk menjaga kedudukan hierarki perundang-undangan supaya selaras dengan amanat dari pada konstitusi dan pancasila, dan isi materil TAP MPR sama dengan Undang-Undang. sebaiknya revisi dari pada Pasal 7 Undang-Undang Nomor 12 Tahun 2011 tentang Pembentukan Perundang-Undangan harus segera dilaksanakan, yaitu dengan menyamakan kedudukan Undang-Undang dengan Ketetapan MPR (TAP MPR)
2. Mekanisme hukum yang baik adalah adanya lembaga yang dapat menguji sebuah Peraturan Perundang-Undangan terhadap peraturan di atasnya. yang dalam hal ini TAP MPR masih belum ada lembaga yang bisa menguji apabila bertetangan dengan Undang-Undang Dasar. Maka apabila kedudukan TAP MPR sejajar dengan Undang-Undang, Mahkamah Konstitusi dapat melaksakan $J u$ dical review terhadap TAP MPR. Sehingga kekosongan hukum dalam pengujian TAP MPR terhadap Undang-Undang Dasar dapat dilaksanakan.

\section{DAFTAR PUSTAKA}

\section{Peraturan Perundang-undangan}

Undang-Undang Dasar Republik Indonesia 1945

Ketetapan Majelis Permusyawaratan Rakyat Nomor III/MPR/200 tentang Sumber Hukum dan Tata Urutan PerundangUndangan.

Undang-Undang Nomor 10 tahun 2004 tentang Pembetukan Peraturan Perundang-Undangan

Undang-Undang Nomor 12 Tahun 2011 tentang Pembentukan Peraturan Perundang-Undangan

Risalah Rapat Panitia Khsusus Rancangan Undang-Undang tentang Pemebentukan peraturan perundang-undangan, tertanggal 2 Maret 2011 


\section{Buku}

Hans Kelsen (Translate by Max Knight), Pure

Theory of Law (Berkley: Berkley University Press, 1967).

Rimdan, Kekuasaan Kehakiman PascaAmandemen Konstitusi, Kencana, 2012.

Widodo Ekatjahjana dan Totok Sudaryanto, Sumber Hukum Tata Negara Formal di Indonesia, PT.Citra Aditya Bakti, Bandung, 2001.

Widodo Ekatjahjana, Pembentukan Peraturan Perundang-Undangan Dasar-Dasar dan Teknik Penyusunannya. PT.
CITRA ADITYA BAKTI, Bandung, 2008.

\section{Jurnal}

Retno Anis sebagaimana dikutip oleh Dian Agug Wicaksono, Jurnal Konstitusi, Volume 10, Nomor 1, Maret 2013.

\section{Internet}

Hanno Kaiser, "Notes on Hans Kelsen's Pure Theory of Law (1st Ed.)", http://www.nigerianlawguru.com/articl es/jurisprudence/KELSEN-

PURETHEORY.pdf(diakses pada 20 Februari 2018 jam 22.00 WIB 